\begin{tabular}{|c|c|c|}
\hline UiNivERSITESI & $\begin{array}{c}\text { Türkiye Tarımsal Araştırmalar Dergisi } \\
\text { dergipark.org.tr/tutad }\end{array}$ & $\begin{array}{l}\text { Turk J Agric Res } \\
\text { 2021, 8(1): 109-115 } \\
\text { ○ TÜTAD } \\
\text { ISSN: 2148-2306 } \\
\text { e-ISSN: 2528-858X }\end{array}$ \\
\hline Bilimin Isüumda & Araştırma Makalesi / Research Article & doi: $10.19159 /$ tutad.844679 \\
\hline
\end{tabular}

\title{
Konvansiyonel Meyve Yetiştiriciliği Yapan Üreticilerin Organik Tarım ve İyi Tarım Uygulamaları Konusundaki Görüşleri: Zonguldak İli Örneği, Türkiye
}

\author{
Osman KILIÇ ${ }^{*}$, Gamze AYDIN ERYILMAZ2 ${ }^{2}$, Serdar ÇAKIR ${ }^{3}$ \\ ${ }^{\prime}$ Ondokuz Mayls Üniversitesi, Ziraat Fakültesi, Tarım Ekonomisi Bölümü, Samsun, TÜRKIYE \\ ${ }^{2}$ Ondokuz Mayls Üniversitesi, Samsun Meslek Yüksekokulu, Park ve Bahçe Bitkileri Bölümü, Samsun, TÜRKIYE \\ ${ }^{3}$ T.C. Tarım ve Orman Bakanlı̆ğ, Çaycuma İlçe Tartm ve Orman Müdürlü̆̈̈̈, Zonguldak, TÜRKIYYE
}

\begin{tabular}{|c|c|}
\hline Geliş Tarihi/Received: 21.12 .2020 & Kabul Tarihi/Accepted: 11.02 .2021 \\
\hline \multicolumn{2}{|l|}{ ORCID ID (Yazar sirasma göre / by author order) } \\
\hline (1D) orcid.org/0000-0002-0129-4034 (1D) orcid.org/0000-0002-44 & cid.org/0000-0002-7168-9656 \\
\hline
\end{tabular}

Öz: Konvansiyonel tarımın insan sağlı̆̆ı ve çevre üzerindeki olumsuz etkilerini ortadan kaldırmak için, son yıllarda organik tarım ve iyi tarım uygulamaları yaygınlaşmış ve buna yönelik araştırmalar önem kazanmıştır. Bu araştırmanın amacı, Türkiye'nin Karadeniz Bölgesinde yer alan Zonguldak ilinde konvansiyonel meyve yetiștiriciliği yapan üreticilerin organik tarım ve iyi tarım uygulamaları konusundaki görüşleri ile gelecekte bu üretim sistemlerine geçme konusundaki düşüncelerinin belirlenmesidir. Araştırma verilerini, konvansiyonel tarım yapan 125 meyve üreticisiyle yapılan anketler oluşturmaktadır. Araştırma sonuçlarına göre, organik tarımda kimyasal gübre kullanıldı̆̆ını düşünen üreticilerin oranı $\% 12.00$, tarım ilacı kullanıldığını düşünenlerin oranı \% 46.40'dır. İyi tarım uygulamalarında ise üreticilerin \% 25.60'1 kimyasal gübre, \% 12.80'i tarım ilacı kullanılmadığını düşünmektedir. Bu sonuçlar, üreticilerin organik tarım ve iyi tarım uygulamaları konusunda yeterli bilgi düzeyine sahip olmadıklarını ve bu sistemlerin uygulanma prensiplerinden yeterince haberdar olmadıklarını göstermektedir. Organik tarıma geçmeyi düşünen üreticilerin oranı \% $28.00 \mathrm{iken}$, bu oran iyi tarım uygulamalarında sadece $\%$ 8.80'dir. Organik tarım ve iyi tarım uygulamalarının üreticiler tarafından benimsenmesi, bu üretim sistemlerinin konvansiyonel tarım ürünlerine göre daha kârlı olmasına bağlıdır. Bu amaçla özellikle son yıllarda artan girdi maliyetleri de dikkate alındığında, organik tarım ve iyi tarım uygulamalarına verilen desteklerin revize edilmesi gerekir.

Anahtar Kelimeler: Meyve yetiştiriciliği, organik tarım, iyi tarım uygulamaları, sürdürülebilir tarım, Zonguldak ili

\section{Conventional Fruit Farmers' Opinions on Organic Agriculture and Good Agricultural Practices: The Case of Zonguldak Province, Turkey}

Abstract: In order to eliminate the negative effects of conventional agriculture on human health and the environment, organic agriculture and good agricultural practices have become widespread in recent years and researches on this has gained importance. The aim of this research is to determine the opinions of farmers engaged in conventional fruit farming on organic agriculture and good agricultural practices in Zonguldak province located in the Blacksea Region of Turkey, and their thoughts on the transition to these production systems in the future. Survey data consist of questionnaires conducted with 125 fruit farmers engaged in conventional agriculture. According to the results of the research, the rate of farmers who think that chemical fertilizers are used in organic agriculture is $12.00 \%$, and the rate of those who think that pesticides are used is $46.40 \%$. In good agricultural practices, $25.60 \%$ of the farmers think that chemical fertilizers are not used, and $12.80 \%$ of them think that pesticides are not used. These results show that the farmers do not have enough knowledge about organic agriculture and good agricultural practices and that they are not sufficiently aware of the application principles of these systems. While the rate of farmers who intend to switch to organic agriculture is $28.00 \%$, this rate is only $8.80 \%$ in good agricultural practices. The adoption of organic agriculture and good agricultural practices by farmers depends on the profitability of these farming systems compared to conventional agricultural products. For this purpose, especially considering the increasing input costs in recent years, the supports given to organic agriculture and good agricultural practices should be revised.

Keywords: Fruit growing, organic agriculture, good agricultural practices, sustainable agriculture, Zonguldak province 


\section{Giriş}

Dünyada artan nüfus ve değişen tüketim alışkanlıkları, tüm sektörlerde olduğu gibi tarımda da verim artışına dayalı üretim modelini temel hedef haline getirmiştir. Böylece yoğun kimyasal girdi ve ileri teknolojik uygulamalar sonucu üretim artmış, ancak tarımsal faaliyetlerden kaynaklanan önemli çevresel sorunlar yıllar geçtikçe belirgin bir şekilde gözlemlenmeye başlanmıştır. Yaşanan bu çevresel sorunlar, mevcut doğal kaynakların etkin kullanımına odaklanan sürdürülebilir tarım sistemlerinin önemini giderek daha fazla ortaya çıkarmıştır. Sürdürülebilir tarım kavramı; tarımsal üretimin agronomik, çevresel, sosyal ve ekonomik boyutlarını dengelemeyi hedefleyen bir yaklaşımdır. Sürdürülebilir tarım; bir yandan verimliliği korurken, diğer yandan çevreye verilen zararı azaltarak kısa ve uzun dönemde ekonomiyi canlı tutmak, tarımla uğraşanların yaşam kalitesini yükseltmek ve buna yönelik uygulamalar geliştirmeyi amaçlamaktadır (Turhan, 2005). İnsan sağlığını ve çevreyi koruyan en yaygın sürdürülebilir tarım sistemlerinden olan organik tarım ve iyi tarım uygulamaları, başta gelişmiş ülkeler olmak üzere bütün ülkelerde her geçen gün daha fazla önem kazanmaktadır.

Organik tarım; toprağı, ekosistemi ve insan sağlığını koruyan, aynı zamanda ekolojik sürece ve biyolojik çeşitliliğe dayanan bir üretim sistemidir. $\mathrm{Bu}$ sistem, ortak bir çevresel fayda ile herkes için adil bir yaşam kalitesi sağlamak amacıyla gelenekçiliği, yenilikçiliği ve bilimi birleştiren bir uygulamadır (Anonymous, 2020). İyi tarım uygulamaları ise, son yıllarda değişen ve küreselleşen g1da ekonomisi ve yaşanan sağlık endişeleri neticesinde, aynı zamanda konuyla ilgili paydaşların gıda kalitesi ve güvenilirliği ile tarımın çevresel sürdürülebilirliğiyle ilgili taahhütleri bağlamında ortaya çıkmıştır. Bu paydaşlar; orta ve uzun vadede gıda güvenliği, gıda kalitesi, üretim etkinliği, çevresel kazanımların belirli hedeflerini karşılayan g1da işleme ve perakende sanayi işletmeleri, çiftçiler, tarım işçileri ve tüketicileri içermektedir (İçel, 2007). Organik tarım ve iyi tarım uygulamaları, sürdürülebilir tarımın sağlanmasında benzer amaçlara sahip olsalar da, benimsedikleri prensipler yönünden farklılıklar göstermektedir. Organik tarım; kimyasal gübre, tarım ilacı, endüstriyel sentetik ürünler ve genetiği değiştirilmiş organizmaların kullanılmaması ilkesine dayanmaktadır (Ahlem ve Hammas, 2017). İyi tarım uygulamalarında ise kimyasal girdi kullanımı söz konusu olmakla birlikte, girdiler insan sağlığına ve çevreye zarar vermeyecek şekilde tatbik edilmektedir (Hasdemir, 2011). İyi tarım uygulamaları kontrollü bir tarımsal faaliyet olup, tüm uygulamaların kayıt altına alınmasını esas almaktadır. Bu kayıtlar; ürünün tür ve çeşidi, kullanılan gübre ve tarım ilacının uygulanma nedeni, zaman1, miktarı, öneriyi yapanların ve uygulayıcıların isimleri, bu konudaki yetkinlikleri, ürünün hasat edileceği süre, su kalitesi ve sulama ile ilgili tüm detayları içermektedir. Böylelikle tarımda izlenebilirlik ve sürdürülebilirlik yerine getirilmiş olmaktadır (Aksoy ve ark., 2013).

Türkiye'de organik tarım ve iyi tarım uygulamalarının artan önemiyle birlikte, bu üretim sistemlerine yönelik üreticilerin alg1 ve tercihlerini ortaya koyan araştırmaların sayısında da artış söz konusudur. Erzurum, Erzincan ve Bayburt illerini kapsayan bir araştırmada; eğitim seviyesi yüksek, arazisi büyük, tarımsal faaliyeti ticari amaçlı yapan, eğitimlere katılan ve Erzurum'da ikamet eden kırsal kadınların organik tarımı benimseme konusunda daha fazla istekli oldukları tespit edilmiştir (Kaya ve Atsan, 2013). Akkaya ve ark. (2006)'na göre, Türkiye'de iyi tarım uygulamalarının gelişimine engel teşkil eden başlıca konular olarak; tarım işletmelerinin küçük ve arazinin parçalı olması, işletmelerde kayıt tutma alışkanlığının olmaması ve üreticilerin örgütlenme sorunları sayılabilir. Türkiye'de yapılan bazı araştırmalar organik tarım ve iyi tarım uygulamalarının benimsenmesinde birçok faktörün etkili olduğunu ortaya koymaktadır. Aydın ilinde yapılan bir araştırmada, kırsal kadınların organik tarımı benimseme olasılığını etkileyen faktörler; babasının çiftçi olması, eğitim düzeyi, hanedeki çocuk sayısı, tarımsal faaliyetlere katılma durumu, mesleki eğitime katılma, kadınlara yönelik projeleri takip etme, yeniliklere açık olma, hayatında idealine yakın olup/olmama durumu, organik tarım konusunda kavramsal olarak bilinçli olup/olmama ve kendine ait gelirin olması olarak belirlenmiştir (Karaturhan ve ark., 2018). Antalya ilinde yapılan bir araştırmada ise, iyi tarım uygulamaları yapma ile sosyal güvence durumu, tarımsal örgütlere üyelik, üye olunan örgüt sayısı ve örgütlerin faydalılığı hakkındaki düşünce arasında anlamlı bir ilişki bulunmuştur (Sayın ve ark., 2016).

Araştırmanın yapıldı̆̆ 1 Zonguldak ilinde, 2019 yılı itibariyle meyve arazisinin \% 92 gibi büyük bir kısmını fındık arazisi oluşturmaktadır (Anonim, 2020a). İlde 276 işletmede ve toplam 4798 dekar arazide organik findık yetiştirilmekte, iyi tarım uygulamaları ise yapılmamaktadır (Anonim, 2020b). Bu araştırmanın amacı, Zonguldak ilinde konvansiyonel meyve yetiştiriciliği yapan üreticilerin organik tarım ve iyi tarım uygulamalarına yönelik görüşlerini ve gelecekte bu üretim sistemine geçme konusundaki düşüncelerini belirlemektir. Organik tarım ve iyi tarım uygulamaları hakkında üretici görüşlerinin ortaya konulması, bu sistemlerin benimsenmesine ve yaygınlaşmasına yönelik çalışmalara katkı 
sağlaması bakımından önemlidir. Organik tarım ve iyi tarım uygulamalarıyla ilgili oluşturulacak politikalarda üretici görüşlerinin de dikkate alınması, çözüm odaklı bir yaklaşım olarak sürdürülebilir tarımın benimsenme ve yayılma başarısını attıracaktır. Araştırma sonuçları, başta politikacı olmak üzere yayım personeli, araştırmacı ve konuyla ilgili diğer tüm paydaşlara yol gösterici olacaktır.

\section{Materyal ve Yöntem}

Araştırma materyalini, konvansiyonel meyve yetiştiriciliği yapan ve çiftçi kayıt sistemine kayıtlı işletmelerle yapılan anketler oluşturmaktadır. Araştırmada, örnekleme birimi olarak meyve arazisi büyüklüğü esas alınmıştır. İşletmeler; 1-6 dekar, 7-13 dekar, 14 dekar ve daha fazla meyve arazisine sahip işletmeler şeklinde üç gruba ayrılmıştır. Anket yapılan işletme sayısı, tabakalı tesadüfi örnekleme yöntemiyle 125 olarak belirlenmiştir (Yamane, 1967). Oransal dağılıma göre işletmeler; birinci grupta 57, ikinci grupta 37 ve üçüncü grupta 31 olarak tespit edilmiştir.

İşletmelerden veri elde etmek için hazırlanan ankette, işletme yöneticisine ait demografik özellikler, organik tarım ve iyi tarım uygulamalarında gübre kullanımı, hastalık, zararlı ve yabancı otlarla mücadele yöntemleri ile bu üretim sistemlerinin insan sağlığına ve çevreye etkileri, ayrıca devlet destekleri konusundaki üretici görüşlerinin tespit edilmesine yönelik sorular yer almaktadır. Örnek işletmelerden anket yoluyla elde edilen veriler 2020 yılına ait olup, veriler işletme büyüklük grupları itibariyle analiz edilmiştir. İşletme büyüklük grupları itibariyle; üreticilere ait cinsiyet, yaş, eğitim, tarımsal deneyim, sosyal güvence ve tarımsal örgüt üyeliği ile üreticilerin organik tarım ve iyi tarım uygulamalarıyla ilgili görüşleri açısından farklılığgn belirlenmesinde kikare testi kullanılmıştır.

\section{Bulgular ve Tartışma}

Anket yapılan işletme yöneticisi konumundaki üreticilerin \% 88.00'1 erkek, \% 12.00'1 kadındır. Üreticilerin \% 8.00'1 40 yaşın altında, \% 30.40'1 4049 yaş grubunda ve \% 61.60' 150 yaş ve üzerindedir. Üreticiler arasında lise (\% 29.03) ve üniversite (\% 19.36) mezunu olanların oranı, üçüncü grupta en yüksektir. İşletmeler büyüdükçe 14 yıl ve daha fazla tarımsal deneyime sahip üreticilerin oranı artmaktadır. Eğitim durumu $(\mathrm{p}<0.01)$ ve tarımsal deneyim $(\mathrm{p}<0.05)$ açısından, işletme büyüklük grupları arasında istatistiki olarak anlamlı farklılık vardır. Her üç işletme büyüklük grubunda da, üreticilerin tamamı sosyal güvenceye sahip ve Ziraat Odası'na üyedir. Tarım Kredi Kooperatifi'ne üye olan yöneticilerin oranı ise, işletme büyüklük gruplarına göre sirasıla \% $17.54, \quad \% 40.54$ ve $\%$ 22.58'dir. İşletme büyüklük grupları itibariyle, üreticilerin üyelik durumu yönünden istatistiki olarak anlamlı bir ilişki vardır $(\mathrm{p}<0.10)$ (Tablo 1).

Anket yapılan üreticilerin organik tarımla ilgili olarak çevreyi koruduğu görüşü \%83.20 ile en fazladır. Bunu, insan sağlığını koruduğu (\% 81.60) ve devlet tarafından desteklendiği ( $\%$ 81.60) görüşleri takip etmektedir. İşletme büyüklük grupları itibariyle, üreticilerin organik tarımla ilgili mekanik mücadele yapılması $(\mathrm{p}<0.05)$, insan sağlı̆̆ı1 koruması $(\mathrm{p}<0.05)$, çevreyi koruması $(p<0.10)$ ve devlet tarafindan desteklenmesi $(p<0.01)$ hakkındaki görüşleri açısından istatistiki olarak anlamlı bir ilişki vardır (Tablo 2). Konuyla ilgili olarak diğer bazı illerde yapılan araştırmalar, üreticilerin organik tarımla ilgili benzer fikirlere sahip olduklarını ortaya koymaktadır. Aydın, İzmir, Manisa ve Muğla illerini kapsayan bir araştırmada, konvansiyonel zeytin üreticilerinin büyük çoğunluğu (\% 77.63) organik tarımı ilaçsız ve gübresiz tarım olarak tanımlarken, \% 19.74'ü doğal üretim, \% 5.92'si kontrollü ve sertifikalı üretim, $\% \quad 5.26$ 'sı ise sağlıklı üretim şeklinde nitelendirmiştir (Adıgüzel ve Kızılaslan, 2020). Çanakkale ilinde organik zeytin yetiştiriciliği yapan üreticilerle yapılan bir araştırma sonucuna göre, organik tarımda insan sağlığına ve doğaya zarar veren kimyasalların kullanılmadığı görüşü ilk sırada yer almıştır (Özsayın ve ark., 2018).

Araştırma sonuçlarına göre, üreticilerin iyi tarım uygulamalarının çevreyi (\% 82.40) ve insan sağlığını (\% 80.00) koruduğuna yönelik görüşleri öne çıkmaktadır. Üreticiler arasında iyi tarım uygulamalarında kimyasal gübre (\% 25.60) ve tarım ilacı (\% 12.80) kullanılmadığını düşünen üreticiler de bulunmaktadır. Üreticilerin iyi tarım uygulamalarıyla ilgili mekanik mücadele yapılması $(p<0.01)$, tarım ilac1 kullanılması $(p<0.01)$, insan sağlı̆̆ını koruması $(p<0.10)$, çevreyi koruması $(p<0.05)$ ve devlet tarafindan desteklenmesiyle $(\mathrm{p}<0.05)$ ilgili görüşleri işletme büyüklük grupları itibariyle istatistiki olarak anlamlı bulunmuştur (Tablo 3). Bu konuda yapılan bazı araştırma sonuçları, üreticilerin kimyasal gübre uygulamasını en fazla kendi tecrübesine göre yaptıklarını ve toprak analizi yaptırma konusunda henüz yeterli bilincin oluşmadığını göstermektedir (Yılmaz ve ark., 2009; Gözener ve ark., 2016; Kızıloğlu ve Kızılaslan, 2017; Yüzbaşığlu, 2020). Üreticilerin iyi tarım uygulamalarına geçtikten sonra kimyasal gübre ve tarım ilacı kullanılmayacağı düşüncesinin, iyi tarım uygulamalarına karşı olumsuz alg1 oluşturacağ 1 ve bu sistemin benimsenmesini zorlaştıracağı açıktır. 
Tablo 1. Üreticilere ait demografik özellikler

\begin{tabular}{|c|c|c|c|c|c|c|c|c|c|c|}
\hline & \multicolumn{2}{|c|}{ 1. grup } & \multicolumn{2}{|c|}{ 2. grup } & \multicolumn{2}{|c|}{ 3. grup } & \multicolumn{2}{|c|}{ Toplam } & \multirow[t]{2}{*}{$\chi^{2}$} & \multirow[t]{2}{*}{$P$} \\
\hline & Say1 & $\%$ & Say1 & $\%$ & Say1 & $\%$ & Say1 & $\%$ & & \\
\hline \multicolumn{9}{|l|}{ Cinsiyet } & \multirow{4}{*}{1.21} & \multirow{4}{*}{0.547} \\
\hline Kadın & 8 & 14.04 & 5 & 13.51 & 2 & 6.45 & 15 & 12.00 & & \\
\hline Erkek & 49 & 85.96 & 32 & 86.49 & 29 & 93.55 & 110 & 88.00 & & \\
\hline Toplam & 57 & 100.00 & 37 & 100.00 & 31 & 100.00 & 125 & 100.00 & & \\
\hline \multicolumn{9}{|l|}{ Yaş } & \multirow{5}{*}{3.77} & \multirow{5}{*}{0.438} \\
\hline$<40$ & 3 & 5.26 & 2 & 5.41 & 5 & 16.13 & 10 & 8.00 & & \\
\hline $40-49$ & 18 & 31.58 & 11 & 29.73 & 9 & 29.03 & 38 & 30.40 & & \\
\hline$>49$ & 36 & 63.16 & 24 & 64.86 & 17 & 54.84 & 77 & 61.60 & & \\
\hline Toplam & 57 & 100.00 & 37 & 100.00 & 31 & 100.00 & 125 & 100.00 & & \\
\hline \multicolumn{9}{|l|}{ Eğitim } & \multirow{6}{*}{33.98} & \multirow{6}{*}{$0.000^{* * *}$} \\
\hline İlkokul & 37 & 64.91 & 15 & 40.54 & 5 & 16.13 & 57 & 45.60 & & \\
\hline Ortaokul & 17 & 29.83 & 12 & 32.43 & 11 & 35.48 & 40 & 32.00 & & \\
\hline Lise & 3 & 5.26 & 6 & 16.22 & 9 & 29.03 & 18 & 14.40 & & \\
\hline Üniversite & - & - & 4 & 10.81 & 6 & 19.36 & 10 & 8.00 & & \\
\hline Toplam & 57 & 100.00 & 37 & 100.00 & 31 & 100.00 & 125 & 100.00 & & \\
\hline \multicolumn{9}{|l|}{ Tartmsal deneyim } & \multirow{4}{*}{56.57} & \multirow{4}{*}{$0.016^{* *}$} \\
\hline$<14$ & 44 & 77.19 & 22 & 59.46 & 8 & 25.81 & 74 & 59.20 & & \\
\hline$\geq 14$ & 13 & 22.81 & 15 & 40.54 & 23 & 74.19 & 51 & 40.80 & & \\
\hline Toplam & 57 & 100.00 & 37 & 100.00 & 31 & 100.00 & 125 & 100.00 & & \\
\hline \multicolumn{9}{|l|}{ Sosyal güvence } & \multirow{5}{*}{3.12} & \multirow{5}{*}{0.537} \\
\hline SSK & 35 & 61.40 & 22 & 59.46 & 18 & 58.06 & 75 & 60.00 & & \\
\hline Bağ-Kur & 15 & 26.32 & 8 & 21.62 & 5 & 16.13 & 28 & 22.40 & & \\
\hline Emekli sandığ 1 & 7 & 12.28 & 7 & 18.92 & 8 & 25.81 & 22 & 17.60 & & \\
\hline Toplam & 57 & 100.00 & 37 & 100.00 & 31 & 100.00 & 125 & 100.00 & & \\
\hline \multicolumn{9}{|l|}{ Tarımsal örgüt üyeliğg ${ }^{1}$} & \multirow{3}{*}{10.96} & \multirow{3}{*}{$0.090^{*}$} \\
\hline Ziraat Odası & 57 & 100.00 & 37 & 100.00 & 31 & 100.00 & 125 & 100.00 & & \\
\hline Tarım Kredi Kooperatifi & 10 & 17.54 & 15 & 40.54 & 7 & 22.58 & 32 & 25.60 & & \\
\hline
\end{tabular}

Tablo 2. Üreticilerin organik tarımla ilgili görüşleri

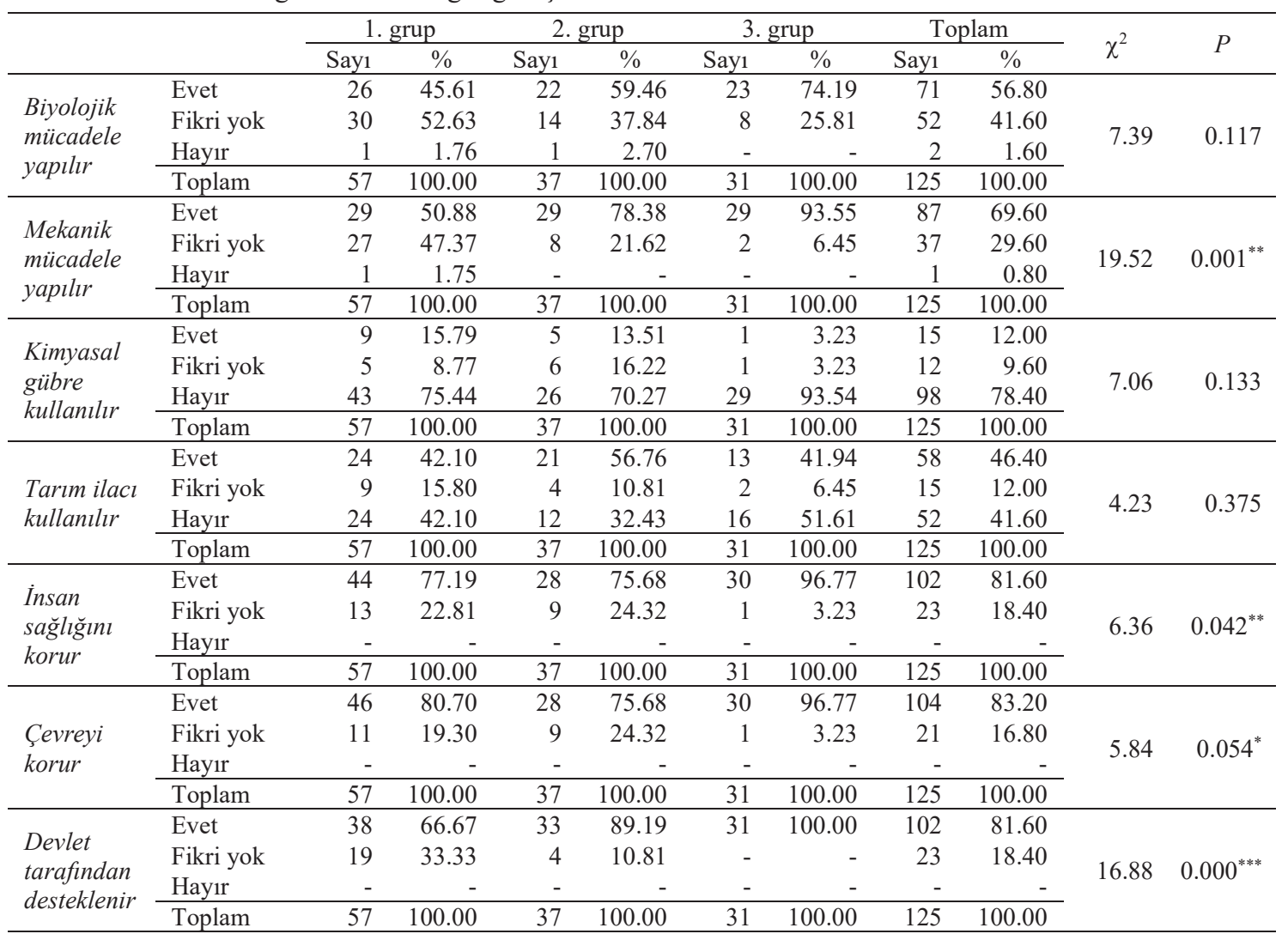

*: \% 10, **: \% 5 ve ***: \% 1 düzeyinde istatistiki olarak anlamlıdır. 
Tablo 3. Üreticilerin iyi tarım uygulamalarıyla ilgili görüşleri

\begin{tabular}{|c|c|c|c|c|c|c|c|c|c|c|c|}
\hline & & \multicolumn{2}{|c|}{ 1. grup } & \multicolumn{2}{|c|}{ 2. grup } & \multicolumn{2}{|c|}{ 3. grup } & \multicolumn{2}{|c|}{ Toplam } & \multirow[t]{2}{*}{$\chi^{2}$} & \multirow[t]{2}{*}{$P$} \\
\hline & & Say1 & $\%$ & Sayı & $\%$ & Say1 & $\%$ & Say1 & $\%$ & & \\
\hline \multirow{4}{*}{$\begin{array}{l}\text { Biyolojik } \\
\text { mücadele } \\
\text { yapılır }\end{array}$} & Evet & 24 & 42.11 & 21 & 56.76 & 23 & 74.19 & 68 & 54.40 & \multirow{4}{*}{11.06} & \multirow{4}{*}{0.026} \\
\hline & Fikri yok & 33 & 57.89 & 15 & 40.54 & 8 & 25.81 & 56 & 44.80 & & \\
\hline & Hayır & - & - & 1 & 2.70 & - & - & 1 & 0.80 & & \\
\hline & Toplam & 57 & 100.00 & 37 & 100.00 & 31 & 100.00 & 125 & 100.00 & & \\
\hline \multirow{4}{*}{$\begin{array}{l}\text { Mekanik } \\
\text { mücadele } \\
\text { yapılır }\end{array}$} & Evet & 26 & 45.61 & 28 & 75.68 & 29 & 93.55 & 83 & 66.40 & \multirow{4}{*}{22.71} & \multirow{4}{*}{$0.000^{* * *}$} \\
\hline & Fikri yok & 31 & 54.39 & 9 & 24.32 & 2 & 6.45 & 42 & 33.60 & & \\
\hline & Hayır & - & - & - & - & - & - & - & - & & \\
\hline & Toplam & 57 & 100.00 & 37 & 100.00 & 31 & 100.00 & 125 & 100.00 & & \\
\hline \multirow{4}{*}{$\begin{array}{l}\text { Kimyasal } \\
\text { gübre } \\
\text { kullanılır }\end{array}$} & Evet & 24 & 42.10 & 14 & 37.84 & 14 & 45.16 & 52 & 41.60 & \multirow{4}{*}{0.47} & \multirow{4}{*}{0.977} \\
\hline & Fikri yok & 18 & 31.58 & 13 & 35.13 & 10 & 32.26 & 41 & 32.80 & & \\
\hline & Hayır & 15 & 26.32 & 10 & 27.03 & 7 & 22.58 & 32 & 25.60 & & \\
\hline & Toplam & 57 & 100.00 & 37 & 100.00 & 31 & 100.00 & 125 & 100.00 & & \\
\hline \multirow{4}{*}{$\begin{array}{l}\text { Tarım ilacı } \\
\text { kullanılır }\end{array}$} & Evet & 33 & 57.90 & 23 & 62.16 & 23 & 74.19 & 79 & 63.20 & \multirow{4}{*}{7.86} & \multirow{4}{*}{$0.097^{*}$} \\
\hline & Fikri yok & 19 & 33.33 & 6 & 16.22 & 5 & 16.13 & 30 & 24.00 & & \\
\hline & Hayır & 5 & 8.77 & 8 & 21.62 & 3 & 9.68 & 16 & 12.80 & & \\
\hline & Toplam & 57 & 100.00 & 37 & 100.00 & 31 & 100.00 & 125 & 100.00 & & \\
\hline \multirow{4}{*}{$\begin{array}{l}\dot{\text { Insan }} \\
\text { sağlı̆̆ını } \\
\text { korur }\end{array}$} & Evet & 44 & 77.19 & 27 & 72.97 & 29 & 93.55 & 100 & 80.00 & \multirow{4}{*}{4.98} & \multirow{4}{*}{$0.083^{*}$} \\
\hline & Fikri yok & 13 & 22.81 & 10 & 27.03 & 2 & 6.45 & 25 & 20.00 & & \\
\hline & Hayır & - & - & - & - & - & - & - & - & & \\
\hline & Toplam & 57 & 100.00 & 37 & 100.00 & 31 & 100.00 & 125 & 100.00 & & \\
\hline \multirow{4}{*}{$\begin{array}{l}\text { Çevreyi } \\
\text { korur }\end{array}$} & Evet & 45 & 78.95 & 28 & 75.68 & 30 & 96.77 & 103 & 82.40 & \multirow{4}{*}{6.04} & \multirow{4}{*}{$0.049^{* *}$} \\
\hline & Fikri yok & 12 & 21.05 & 9 & 24.32 & 1 & 3.23 & 22 & 17.60 & & \\
\hline & Hayır & - & - & - & - & - & - & - & - & & \\
\hline & Toplam & 57 & 100.00 & 37 & 100.00 & 31 & 100.00 & 125 & 100.00 & & \\
\hline \multirow{4}{*}{$\begin{array}{l}\text { Devlet } \\
\text { tarafindan } \\
\text { desteklenir }\end{array}$} & Evet & 17 & 29.82 & 22 & 59.46 & 19 & 61.29 & 58 & 46.40 & \multirow{4}{*}{12.47} & \multirow{4}{*}{$0.014^{* *}$} \\
\hline & Fikri yok & 34 & 59.65 & 14 & 37.84 & 11 & 35.48 & 59 & 47.20 & & \\
\hline & Hayır & 6 & 10.53 & 1 & 2.70 & 1 & 3.23 & 8 & 6.40 & & \\
\hline & Toplam & 57 & 100.00 & 37 & 100.00 & 31 & 100.00 & 125 & 100.00 & & \\
\hline
\end{tabular}

*: \% 10, **: \% 5 ve ***: \% 1 düzeyinde istatistiki olarak anlamlıdır.

Anket yapılan üreticilerden organik tarım yapma düşüncesi olanların oranı \% $28.00 \mathrm{iken,} \mathrm{bu}$ oran iyi tarım uygulamalarında \% 8.80'dir. İşletmeler büyüdükçe her iki üretim sistemini yapmayı düşünenlerin oranı artmakla birlikte, organik tarım ve iyi tarım uygulamalarına geçme konusunda yeterli farkındalığın oluştuğunu söylemek zordur. İşletme büyüklük grupları itibariyle, üreticilerin organik tarım $(\mathrm{p}<0.01)$ ve iyi tarım uygulamalarına $(\mathrm{p}<0.10)$ geçme düşünceleri açısından istatistiki olarak anlamlı bir ilişki vardır (Tablo 4). Samsun ilinde yapılan bir araştırmada, konvansiyonel tarım yapan üreticilerin \% 74.3'ünün organik tarıma geçmeyi düşündüğü, bu tarım sistemine geçmek istemede en etkili faktörün ise verilen destekler olduğu tespit edilmiştir (Karabaş ve Gürler, 2011). Verimin düşmesi ve sertifikasyon işlemleriyle birlikte üretim maliyetinin artması nedeniyle, organik tarım üreticiler tarafindan çok fazla tercih edilmemektedir. İyi tarım uygulamalarında ise, sertifikasyon maliyetinin yüksek olması, prim fiyatının olmayışı ve prosedürün fazla olması bu üretim sisteminin yaygınlaşmasını geciktirmektedir (Pezikoğlu ve ark., 2019).

Tablo 4. Üreticilerin organik tarım ve iyi tarım uygulamalarına geçme düşüncesi

\begin{tabular}{|c|c|c|c|c|c|c|c|c|c|c|}
\hline & \multicolumn{2}{|c|}{ 1. grup } & \multicolumn{2}{|c|}{ 2. grup } & \multicolumn{2}{|c|}{ 3. grup } & \multicolumn{2}{|c|}{ Toplam } & \multirow[t]{2}{*}{$\chi^{2}$} & \multirow[t]{2}{*}{$P$} \\
\hline & Say1 & $\%$ & Sayı & $\%$ & Say1 & $\%$ & Sayı & $\%$ & & \\
\hline \multicolumn{11}{|l|}{ Organik tarım } \\
\hline Düşünüyor & 9 & 15.79 & 8 & 21.62 & 18 & 58.07 & 35 & 28.00 & \multirow{4}{*}{21.77} & \multirow{4}{*}{$0.000^{* * *}$} \\
\hline Karars1z & 22 & 38.60 & 11 & 29.73 & 2 & 6.45 & 35 & 28.00 & & \\
\hline Düşünmüyor & 26 & 45.61 & 18 & 48.65 & 11 & 35.48 & 55 & 44.00 & & \\
\hline Toplam & 57 & 100.00 & 37 & 100.00 & 31 & 100.00 & 125 & 100.00 & & \\
\hline \multicolumn{11}{|c|}{ İyi tarım uygulamaları } \\
\hline Düşünüyor & 3 & 5.26 & 3 & 8.11 & 5 & 16.13 & 11 & 8.80 & \multirow{4}{*}{9.00} & \multirow{4}{*}{$0.061^{*}$} \\
\hline Kararsiz & 9 & 15.79 & 10 & 27.03 & 11 & 35.48 & 30 & 24.00 & & \\
\hline Düşünmüyor & 45 & 78.95 & 24 & 64.86 & 15 & 48.39 & 84 & 67.20 & & \\
\hline Toplam & 57 & 100.00 & 37 & 100.00 & 31 & 100.00 & 125 & 100.00 & & \\
\hline
\end{tabular}

*: \% 10 ve ***: \% 1 düzeyinde istatistiki olarak anlamlıdır. 


\section{Sonuç ve Öneriler}

Organik tarım ve iyi tarım uygulamaları, insan sağlığını ve çevreyi gözeten aynı zamanda tarımsal faaliyetlerin sürdürülebilirliğini ve gelişimini destekleyen üretim sistemleri olsalar da, henüz dünya nüfusunun beslenmesine yetecek üretim potansiyeline sahip değildir. $\mathrm{Bu}$ nedenle organik tarım ve iyi tarım uygulamaları yapan üretici sayısının artırılması için, öncelikle bu sistemlerle ilgili üretici görüş ve beklentilerinin belirlenerek olası engellerin ortadan kaldırılması gerekir. Zonguldak ilinde yapılan bu araştırmanın sonuçları, organik tarım ve iyi tarım uygulamalarıyla ilgili meyve üreticilerinin genel olarak benzer düşüncelere sahip olduklarını göstermektedir. Diğer bir ifadeyle üreticiler organik tarım ve iyi tarım uygulamalarının prensipleri arasındaki farkı net bir şekilde ayırt edememektedir. Üreticiler arasında organik tarımda olduğu gibi, iyi tarım uygulamalarında da kimyasal girdi kullanılmadığını düşünenler vardır. Organik tarım ve iyi tarım uygulamaları konusundaki bilgi yetersizliği, bu üretim sistemlerinin yaygınlaşmasını engelleyen sorunların başında gelmektedir. $\mathrm{Bu}$ nedenle üreticilerin organik tarım ve iyi tarım uygulamalarıyla ilgili bilgi düzeylerini, görüşlerini ve ileriye dönük beklentilerini dikkate alan bir politikanın oluşturulması, bu üretim sistemlerinin yaygınlaşmasına ve sürdürülebilirliğine önemli katkı sağlayacaktır.

Araştırma sonuçlarına göre, üreticilerin organik tarım konusunda nispeten daha fazla bilgiye sahip oldukları söylenebilir. Ancak her iki üretim sisteminin de bütün özellikleriyle üreticiler tarafından yeterince kavranmadığı anlaşılmaktadır. $\mathrm{Bu}$ üretim sistemlerinin kendine has bir takım farklı prensiplerinin olması, üreticilerin bu üretim sistemleriyle ilgili doğru bilgilendirilmelerini sağlayacak eğitim çalışmalarının gerekliliğini ortaya koymaktadır. Üreticiler organik tarım konusunda daha fazla istekli olsalar da, genel olarak her iki sisteme geçmeye yönelik tutumun istenilen düzeyde olduğu söylenemez. Üreticilerin konuyla ilgili paydaşlar tarafından eğitilmesinin, organik tarım ve iyi tarım uygulamalarının benimsenmesini olumlu yönde etkileyeceği açıktır. $\mathrm{Bu}$ tarım sistemlerinin benimsenmesiyle ilgili olarak, Tarım ve Orman Bakanlığı'na bağlı İl/İlçe Müdürlükleri tarafından gerçekleştirecek toplantılara üretici katılımının artırılması önemlidir. Bu konuda muhtar ve köyde sözü geçen önder üreticilerin, sürdürülebilir tarıma geçiş için örnek teşkil etmeleri etkili bir yöntem olacaktır.

Organik tarım ve iyi tarım uygulamalarında ürün sayısının artırılması, bu ürünlere olan tüketici talebiyle doğru orantılıdır. Ancak organik ve iyi tarım ürünleri, konvansiyonel tarım ürünlerine göre daha yüksek fiyatla satılmaktadır. Bu durumda, düşük ve orta gelirli tüketicilerin organik tarım ve iyi tarım ürünlerini satın almaları zorlaşmaktadır. Ayrıca üreticilerin de, pazarda alıcısı az olan bu ürünlerin üretimine karşı olumlu tutum sergilemeleri beklenemez. $\mathrm{Bu}$ nedenle fiyatların daha makul seviyelere çekilmesi için üretim maliyetlerinin düşürülmesi gerekir. Organik tarım ve iyi tarım ürünlerinin tüketiciler tarafından daha fazla tercih edilmesiyle, bu ürünlere yönelik pazarlama olanakları da artacaktır. Bu durum, konvansiyonel tarım yapan üreticilerin organik ve iyi tarım uygulamalarına olan ilgisini artıracaktır. Organik ve iyi tarım ürünlerinde pazarlama imkânlarının genişletilmesi ve üretim maliyetinin düşürülmesinin yanı sıra, girdilerin temininde kolaylık sağlanması bu üretim sistemlerine yönelik başlıca tedbirler olarak ele alınmalıdır. Organik tarım ve iyi tarım uygulamalarına alan bazlı verilen parasal desteklerin üretim maliyetlerini dikkate alacak şekilde revize edilmesi, hem bu üretim sistemlerine devam eden hem de yeni üreticilerin bu sistemleri benimsemeleri açısından önemli katkı sağlayacaktır. Organik tarım ve iyi tarım uygulamalarının benimsenmesi zaman alacak olsa da, üretici ve tüketicilerde oluşacak motivasyon ve farkındalıktan dolayı gelecek yıllarda önemli bir mesafe alınmış olacaktır.

\section{Kaynaklar}

Adıgüzel, F., Kizılaslan, N., 2020. Ege Bölgesinde organik zeytin üretiminin tercih edilmesinde etkili faktörler. Gaziosmanpaşa Bilimsel Araştırma Dergisi, 9(2): 1-12.

Ahlem, Z., Hammas, M.A., 2017. Organic farming: A path of sustainable development. International Journal of Economics \& Management Sciences, 6(5): 2-7.

Akkaya, F., Yalcin, R., Özkan, B., 2006. Good agricultural practices (GAP) and its implementation in Turkey. Acta Horticulturae, 699(3): 47-52.

Aksoy, A., Dıvrak, B.B., Sütlü, E., 2013. İyi Tarım Uygulamaları El Kitabı. (http://awsassets.wwftr. panda.org/), (Erişim tarihi: 29.03.2015).

Anonim, 2020a. Bitkisel Üretim İstatistikleri. Türkiye İstatistik Kurumu, (https://biruni.tuik.gov.tr/medas/ ?kn=92\&locale=tr), (Erişim tarihi: 29.12.2020).

Anonim, 2020b. Zonguldak İl Tarım ve Orman Müdürlüğü Kayıtları.

Anonymous, 2020. Definition of Organic Agriculture. (https://www.ifoam.bio/why-organic/organic-land marks/definition-organic), (Erişim tarihi: 20.11.2020).

Gözener, B., Say1lı, M., Yurdabakan, M., 2016. Önemli ürünlerde gübre kullanım durumu: Tokat ili Kazova yöresi örneği. Gaziosmanpaşa Üniversitesi Ziraat Fakültesi Dergisi, 33(2): 41-47. 
Hasdemir, M., 2011. Kiraz yetiştiriciliğinde iyi tarım uygulamalarının benimsenmesini etkileyen faktörlerin analizi. Doktora Tezi, Ankara Üniversitesi Fen Bilimleri Enstitüsü, Ankara.

İçel, C.D., 2007. Avrupa Birliği Ülkelerinde İyi Tarım Uygulamaları ve Türkiye ile Karşılaştırılması. AB Uzmanlık Tezi, T.C. Tarım ve Köyişleri Bakanlığı Dış İlişkiler ve Avrupa Birliği Koordinasyon Dairesi Başkanlığı, Ankara.

Karabaş, S., Gürler, A.Z., 2011. Organik tarım ve konvansiyonel tarım yapan işletmelerin karşılaştırmalı analizi. Karamanoğlu Mehmetbey Üniversitesi Sosyal ve Ekonomik Araştırmalar Dergisi, 13(21): 75-84.

Karaturhan, B., Uzmay, A., Koç, G., 2018. Factors affecting the probability of rural women's adopting organic farming on family farms in Turkey. Ege Üniversitesi Ziraat Fakültesi Dergisi, 55(2): 153160.

Kaya, T.E., Atsan, T., 2013. Kırsal kadının organik tarımı benimsemesini etkileyen faktörler üzerine bir araştırma (TRA1 Bölgesi örneği). Atatürk Üniversitesi Ziraat Fakültesi Dergisi, 44(1): 43-49.

Kızıloğlu, R., Kızılaslan, N., 2017. Kahramanmaraș ili merkez ilçe kırsalında çiftçilerin gübre kullanım durumu. Türk Tarım-Gida Bilim ve Teknoloji Dergisi, 5(1): $18-23$.
Özsayın, D., Tan, S., Everest, B., 2018. Organik zeytin üreticilerinin sosyo-ekonomik yapısı ve organik tarım konusundaki bilgi düzeyi ve yaklaşımları. Türk Tarım-Gıda Bilim ve Teknoloji Dergisi, 6(11): 16221629.

Pezikoğlu, F., Adanacıŏlu, H., Mısır, G., Öztürk, M., Temel, M., 2019. Bazı illerde yeșil tarım sistemleri ile konvansiyonel tarım sistemi üreticilerinin sosyoekonomik özellikleri. VI. Organik Tarım Seтровуити, 15-17 May1s, İzmir, s: 51-57.

Sayın, B., Çelikyurt, M.A., Kuzgun, M., Aydın, B., 2016. Örtüaltı sebze yetiştiriciliğinde iyi tarım uygulamaları yapmayı etkileyen faktörlerin belirlenmesi. XII. Ulusal Tarım Ekonomisi Kongresi, 25-27 May1s, Isparta, s: 1975-1984.

Turhan, Ş., 2005. Tarımda sürdürülebilirlik ve organik tarım. Tarım Ekonomisi Dergisi, 11(1): 13-24.

Yamane, T., 1967. Elemantary Sampling Theory. Printice Hall Inc. Englewood Cliffs, Nt.

Yılmaz, H., Demircan, V., Gül, M., 2009. Üreticilerin kimyasal gübre kullanımında bilgi kaynaklarının belirlenmesi ve tarımsal yayım açısından değerlendirilmesi. Süleyman Demirel Üniversitesi Ziraat Fakültesi Dergisi, 4(1): 31-44.

Yüzbaşığlu, R., 2020. Üreticilerin kimyasal gübre kullanım bilinç düzeylerinin incelenmesi: Tokat Merkez ilçe örneği. Turkish Journal of Agricultural Engineering Research, 1(2): 452-465. 